\title{
Priporočila za zdravljenje aken, povzeta po najnovejših mednarodnih smernicah
}

\section{Recommendations for the treatment of acne, summarised according to the latest international guidelines}

Manca Valjavec, Mateja Starbek Zorko

\section{Izvleček}

Navadne akne (Acne vulgaris) so pogosta kronična kožna bolezen, ki se pojavlja pri ljudeh vseh starostnih skupin, najpogosteje pri najstnikih. Nastanejo na seboroičnih predelih kože. Ker so najpogosteje prisotne na koži obraza, pogosto pomembno vplivajo na kakovost življenja er so lahko razlog pridruženih duševnih težav in motenj. V patogenezi nastanka aken so pomembni štirje patogenetski dejavniki, ki so ključne terapevtske tarče. $V$ preglednem prispevku predstavljamo klinično sliko aken in stopenjsko zdravljenje, ki smo ga povzeli po evropskih in ameriških smernicah. Opisujemo lokalno in sistemsko zdravljenje ter tudi druge načine zdravljenja, ki mora biti vedno prilagojeno posamezniku ter je odvisno od resnosti bolezni, spola, starosti in pridruženih bolezni.

Ključne besede: akne, patogeneza, zdravljenje.

\begin{abstract}
Acne vulgaris is a common, chronic skin disease that can occur in people of all ages, most commonly in teenagers. Acne occurs on the seborrhoeic areas of the skin, most often on the face, hence it can have a significant impact on the patient's quality of life, and it can be the cause of associated psychological problems and disorders. There are four important pathogenetic factors in the pathogenesis of acne that are key therapeutic targets. In the review article, we present the clinical picture of acne and staged treatment, which has been summarised according to the European and American guidelines for the treatment of acne. We present the local and systemic treatment and other treatment methods, which should always be individually tailored to the patient and dependent on the severity of the disease, gender, age and associated diseases.
\end{abstract}

Key words: acne, pathogenesis, treatment. 


\section{Uvod}

Navadne ali vulgarne akne (Acne vulgaris) so pogosta kronična kožna bolezen. Srečamo jih tako pri dojenčkih kot pri odraslih, najpogostejše pa so pri najstnikih (1). Večinoma se prve spremembe na koži pojavijo ob vstopu v puberteto in v različnih oblikah prizadenejo do $85 \%$ mladih (2).

Pri novorojenčkih se akne pojavijo zaradi materinih androgenih hormonov $v$ krvi in večinoma do prvega leta starosti izzvenijo. Pojav aken v predpubertetnem obdobju, po starosti 1,5 leta, nam mora vzbuditi pozornost; takrat moramo poiskati vzroke $v$ morebitnem hormonskem neravnovesju in otroka napotiti k endokrinologu. Akne se lahko pojavijo tudi v odraslosti, predvsem pri ženskah. Vzroki so lahko različni, možni sprožilci pa so zdravila, kozmetični izdelki, kajenje, stres, prehrana in endokrine motnje $(1,3)$.

Akne nastanejo na predelih s številnimi lojnicami, na t. i. seboroičnih predelih kože, predvsem na obrazu, relativno pogosto tudi na hrbtu, prsnem košu in ramenskem obroču (1).

Bolezen praviloma posameznika telesno bistveno ne omejuje. Ker so akne najpogostejše na koži obraza, so lahko vzrok manjše samozavesti in okrnjenega socialnega življenja, kar lahko vodi $v$ depresijo (2).

Akne zdravimo stopenjsko po strokovnih smernicah. Zdravljenje je vedno prilagojeno posamezniku ter odvisno od resnosti bolezni, spola, starosti in pridruženih bolezni (3).

\section{Etiologija in patogeneza}

Pomemben vpliv na nastanek aken ima dedna nagnjenost. $V$ nastanek aken je verjetno vključenih več genov, med njimi geni za citokrom P450-1A1 in geni za nekatere encime, ki so vključeni v presnovo androgenov $(1,4,5)$. $V$ genetskih raziskavah so ugotavljali povezavo med disregulacijo $v$ signal- ni poti, pri kateri sodeluje transformirajoči rastni dejavnik beta (TGF- $\beta$ ), in dovzetnostjo za akne (6). Tudi okoljski dejavniki so verjetno pomembni pri razširjenosti aken. $V$ zadnjem času pozornost usmerjajo v prehrano. $\checkmark$ posameznih raziskavah so potrdili povezavo med poslabšanjem aken ter uživanjem kravjega mleka in mlečnih izdelkov (8). Tudi prehrana $z$ visokim glikemičnim indeksom posredno vpliva na povečano koncentracijo spolnih hormonov, kar vodi v povečano izločanje loja in s tem na poslabšanje aken $(3,7,9)$. Zaradi odsotnosti randomiziranih raziskav, $v$ katerih bi potrdili učinek sprememb prehranskih navad, rutinsko za zdaj ne priporočajo posebnih diet (2).

Tudi duševni stres lahko vpliva na poslabšanje različnih kožnih bolezni, med drugim aken. Stres namreč verjetno posredno vpliva na izločanje androgenih hormonov, kar povzroča povečano izločanje loja in s tem poslabšanje aken (3).

Akne so bolezen, ki prizadene pilosebacealne folikle. Ti se zamašijo $s$ čepki iz loja in odluščenih celic kože (keratinocitov). Sledi vnetje in razvije se tipična klinična slika. Ključni patogenetski dejavniki, ki igrajo vlogo pri razvoju aken, so: i) prekomerna tvorba/ izločanje loja (seboreja), ii) folikularna hiperkeratinizacija in nenormalna deskvamacija (luščenje), iii) kolonizacija foliklov z bakterijami Cutibacterium (Propionibacterium acnes) in iv) kompleksni imunski mehanizmi, ki sodelujejo pri nastanku vnetja. Ti dejavniki so tudi ključne terapevtske tarče (2).

Na prekomerno izločanje loja (seborejo) vplivajo androgeni hormoni (testosteron, 5-alfa-dihidrotestosteron, androsteron, dihidroepiandrosteron sulfat), ki povzročajo hipertrofijo lojnic in pospešujejo nastanek roženih čepov (odmrle kožne celice, sprijete z lojem) v izvodilih lasnih mešičkov. Nastanejo t. i. mikrokomedoni. Mikrokomedoni se lahko odmašijo sami od sebe z običajno regeneracijo kože. Če se mikrokomedon ne odmaši, se razvije v nevnetno obliko kožne nepravilnosti, ki jo imenujemo komedon (t. i. ogrc). Komedon z belo kapico (angl. whitehead) ali zaprti komedon je majhna bela papula, ki je s prostim očesom včasih ne vidimo. Črni komedon (angl. blackhead) ali odprti komedon nastane, ko se izvodilo lasnega mešička odpre in loj, pomešan s kožnim pigmentom melaninom, oksidira, kar vidimo kot papulo s črnorjavim vrhom. Vsebina komedona počasi prehaja na površje.

Bakterije Cutibacterium imajo v ujetem loju ugodne razmere za razmnoževanje in lahko v pilosebacealnem foliklu in tudi okolnem tkivu povzročijo blaga do huda vnetja. Bakterije razgrajujejo trigliceride $v$ glicerol in proste maščobne kisline, ki so komedogene, povzročajo folikularno hiperkeratozo in so kemotaktični dejavnik za levkocite, kar vodi do vnetja (1).

\section{Klinična razdelitev aken}

Akne klinično razdelimo na:

1. primarne, neinflamatorne spremembe (mikrokomedomi, zaprti in odprti komedoni);

2. sekundarne oz. inflamatorne spremembe (papule, papulo-pustule, nodusi, abscesi);

3. postinflamatorne spremembe (atrofične in hipertrofične brazgotine) (1).

Zaprti komedoni se klinično kažejo kot drobne bele papule ali papule kožne barve, odprti komedoni pa kot papule s črnorjavim vrhom (Slika 3).

Papulopustulozne akne so drobne rdečkaste papule in pustule, ki so boleče na pritisk (Slika 1 in 2). Nastanejo ob vnetju in posledičnem razpadu foliklov.

Nodusi nastanejo zaradi širjenja vnetja po razpadu foliklov $v$ globljih plasteh kože (Slika 4). Imajo težnjo po združevanju v boleče abscese, ki se drenirajo skozi fistule na površini kože (značilno 


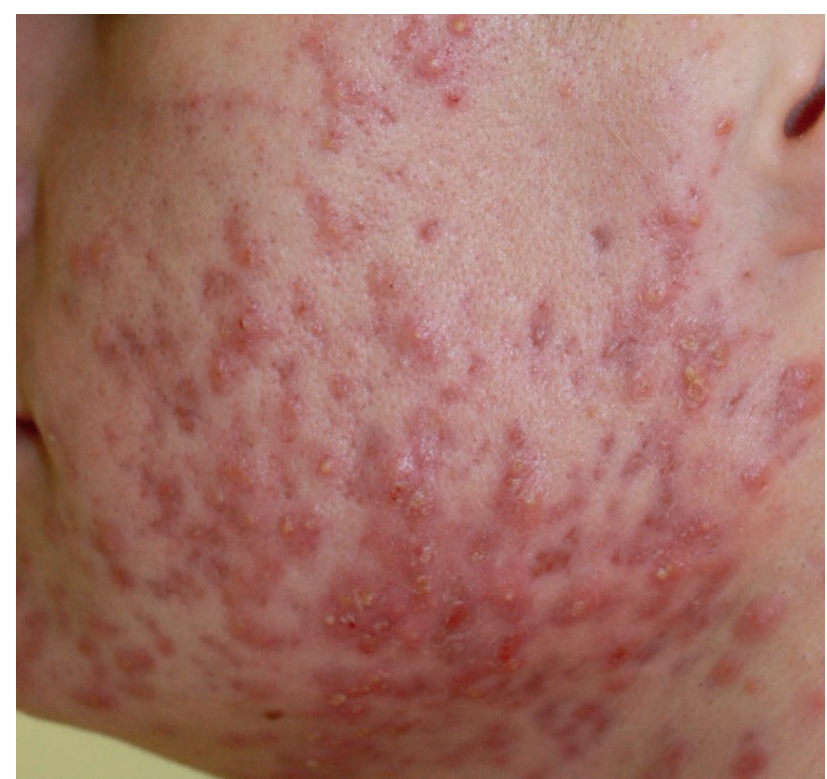

SLIKA 1. HUDE PAPULOPUSTULOZNE AKNE PRED ZDRAVLJENJEM. FIGURE 1. SEVERE PAPULOPUSTULAR ACNE BEFORE TREATMENT. (FOTO: BRANKO PIRŠ, DR. MED.)

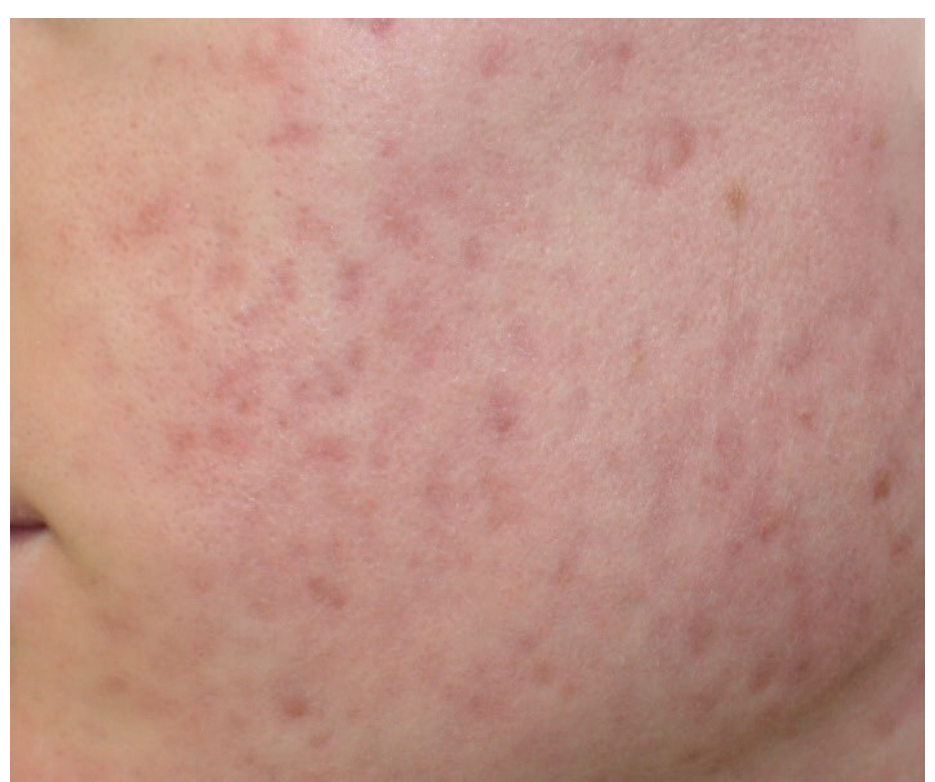

SLIKA 2. PAPULOPUSTULOZNE AKNE PO ZDRAVLJENJU.

FIGURE 2. PAPULOPUSTULAR ACNE AFTER TREATMENT. (FOTO: BRANKO PIRŠ, DR. MED.) za konglobatne akne). Tovrstne spremembe pogosto pustijo posledice $v$ obliki atrofičnih in hipertrofičnih brazgotin (1).

Druge oblike aken so: i) acne fulminans s pridruženo sistemsko prizadetostjo s povišano telesno temperaturo in pojavom artritisa; ii) hidradenitis suppurativa (t. i. inverzne akne), za katere je značilen pojav pustul, nodusov in abscesov, najpogosteje pod pazduhami, ingvinalno ali glutealno; iii) acne exoriée pri ljudeh, ki si akne razpraskajo, najpogosteje pri mladih ženskah z opraskaninami, atrofičnimi brazgotinami, hiperpigmentacijo; iv) mehanske akne, ki nastanejo po dolgotrajnem pritisku (npr. pri violinistih na vratu); v) acne venenata, ki nastanejo po stiku z različnimi mazili, kozmetičnimi pripravki in kemikalijami; vi) medikamentozne akne, ki spremljajo uživanje kortikosteroidov, snovi z jodom in bromom, nekaterih tuberkulostatikov, vitamina $B$, velikih odmerkov vitamina $\mathrm{D}$, litija; vii) acne aestivalis, ki nastanejo zaradi izpostavljenosti soncu spomladi ali na začetku poletja in se kažejo kot monomorfne rdeče, keratotične papule (1, 10-12).

Za potrebe zdravljenja akne razdelimo na blage, zmerne in hude, čeprav univerzalnega sistema za oceno resnosti aken ni (2).

Za blage vulgarne akne so značilne majhne $(<5 \mathrm{~mm}$ ) komedonske ali vnete papule ali pustule brez brazgotin. Praviloma je prizadeto eno področje kože ali pa vidimo razmeroma malo sprememb na več kot enem predelu telesa. Nodusov ne opažamo.

Za zmerne vulgarne akne so značilni številni vidni komedoni ali številne vnete papule ali pustule.

Pri hudih vulgarnih aknah opažamo noduse, prizadetost več telesnih področij kože in pridružene brazgotine.

Pri izbiri zdravljenja nam pomagata ocena resnosti aken in prepoznavanje posledic vulgarnih aken, kot so brazgotine in povnetna hiperpigmentacija (13).

\section{Zdravljenje aken}

Z zdravljenjem želimo preprečiti nastanek mikrokomedonov, zmanjšati izločanje loja, umiriti vnetje in/ali preprečiti nastanek posledic, kot so hiperpigmentacije in brazgotine (14).

Za odločitev o uvedbi ustreznega zdravljenja aken ocenimo vrsto prevladujočih sprememb pri aknah (komedoni in/ali vnete papule, pustule ali nodusi), resnost aken (blage, zmerne, hude) in razširjenost bolezni ter ocenimo prisotnost kožnih sprememb, kot so povnetne hiperpigmentacije, povnetni eritem ali brazgotine. Zelo pomembno je, da se z bolnikom natančno pogovorimo in poskušamo ugotoviti morebitne dejavnike, ki akne poslabšajo ali celo povzročajo (komedogeni izdelki za nego kože, zdravila, ki povzročajo akne, znaki ali simptomi z aknami povezanih endokrinoloških motenj). Oceniti moramo tudi, kako močno bolezen vpliva na kakovost bolnikovega življenja, saj nam vsi ti podatki pomagajo pri izbiri ustreznega zdravljenja (13). 


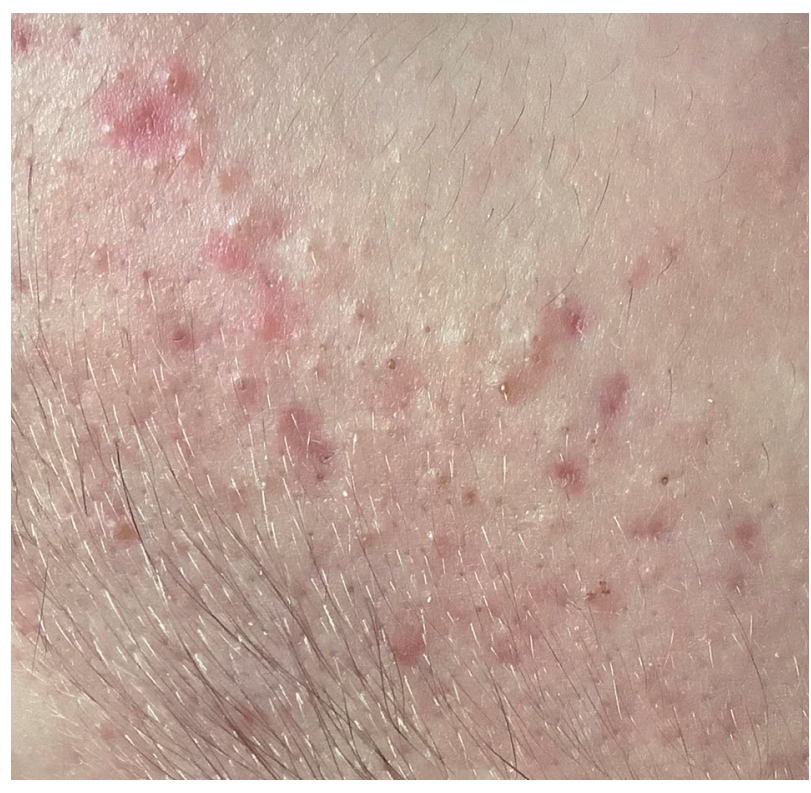

SLIKA 3. KOMEDONSKE AKNE.

FIGURE 3. COMEDONAL ACNE. (FOTO: BRANKO PIRŠ, DR. MED.)

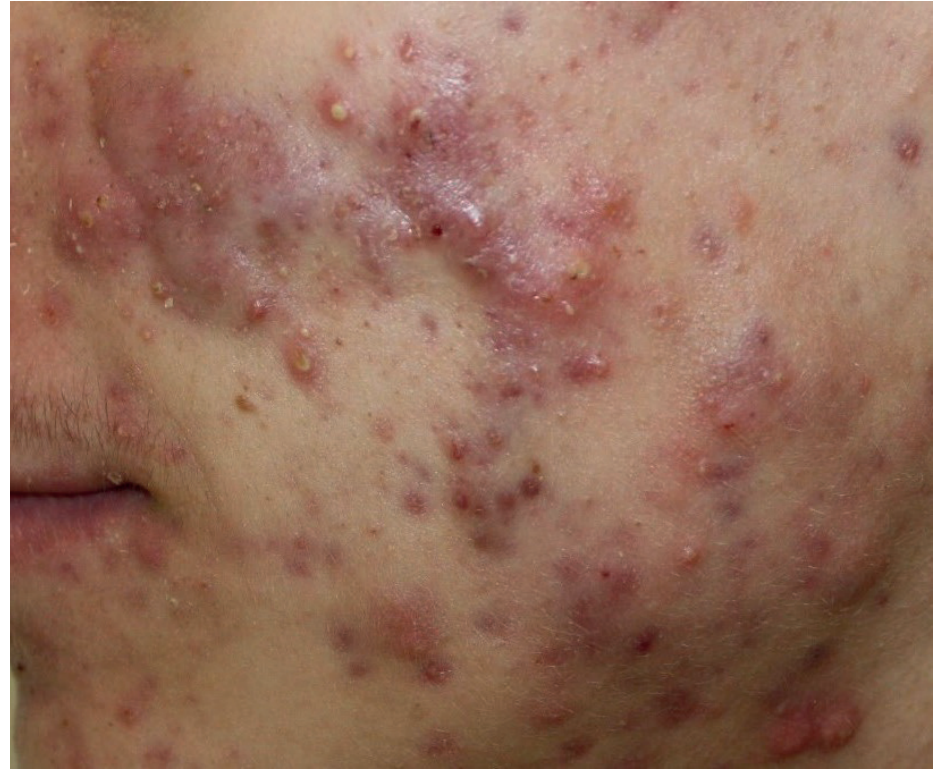

SLIKA 4. NODULOCISTIČNE AKNE.

FIGURE 4. NODULOCYSTIC ACNE. (FOTO: BRANKO PIRŠ, DR. MED.)
Za uspešno zdravljenje aken je pomembno, da bolnika in svojce seznanimo s potekom zdravljenja, saj se izboljšanje ne pojavi takoj po pričetku zdravljenja, pač pa so običajno potrebni 2-3 meseci doslednega upoštevanja terapevtskega režima. Odzivi na zdravljenje se pri posameznih bolnikih razlikujejo in lahko zahtevajo spremembe v načinu zdravljenja, da bo bolnik zdravljenje dobro prenašal in ga tudi dosledno izvajal. Pogosto sta potrebni dolgotrajno vzdrževalno zdravljenje ter tesno sodelovanje bolnika in zdravnika, največkrat daljše obdobje. Vse to od praviloma precej neučakanih najstnikov zahteva veliko potrpežljivosti, kar je lahko dodaten razlog neuspešnosti predpisanega zdravljenja $(3,13,14)$.

Pri svetovanem zdravljenju je zelo pomembna pravilna nega kože, kar pomeni redno vsakodnevno umivanje kože z ustreznimi mili, ki pomagajo vzdrževati ustrezno vrednost $\mathrm{pH}$ kože in zmanjšajo število bakterij na koži. Kozmetika, ki jo bolniki uporabljajo, naj bo nekomedogena, na vodni osnovi in brez umetnih konzervansov ali dišav. Pravilni negi sledi izvajanje predpisanega lokalnega ali sistemskega zdravljenja.

Najpogostejša napaka pri negi je stiskanje aken, ki lahko povzroči dodatno vnetje, pri nekaterih pa zaušča hiperpigmentacije ali rane, ki se - če so globoke - celijo z brazgotino $(3,13)$.

\section{Zdravljenje blage oblike aken}

Lokalno zdravljenje je osnovni način zdravljenja blagih aken. Uporabljamo topikalne retinoide. Kot alternativa retinoidom sta na voljo azelainska ali salicilna kislina, poslužujemo pa se tudi benzoil peroksida in topikalnih antibiotikov.

Topikalni retinoidi (tretinoin, adapalen)

Topikalne retinoide uporabljamo predvsem pri komedonskih aknah. So deri- vati vitamina $A$, ki se vežejo na jedrne receptorje znotraj keratinocitov, kompleks retinoid-receptor pa vstopi v jedro in stimulira transkripcijo določenih genov. Posledica je normalizacija folikularne keratinizacije, ki se kaže v zmanjšani okluziji foliklov in s tem v zmanjšanem nastanku mikrokomedonov (2).

Pri bolnikih, ki imajo blage papulopustulozne ali mešane (komedonske in papulopustulozne) akne, topikalnemu retinoidu dodamo protimikrobna zdravila (benzoil peroksid ali topikalni antibiotik), s čimer zmanjšamo število bakterij Cutibacterium na koži (13).

Topikalni retinoid nanesemo $v$ tanki plasti na prizadeto kožo enkrat na dan, zaradi fotolabilnosti, ki je bila ugotovljena pri tretinoinu, najbolje zvečer. Če bolnik poleg topikalnega retinoida prejema tudi protimikrobno zdravljenje $z$ benzoil peroksidom, benzoil peroksid nanesemo zjutraj, topikalni retinoid pa zvečer. Skupaj ju ne nanašamo zato, ker je tretinoin ob izpostavitvi benzoil peroksidu zaradi 
oksidacije manj stabilen pa tudi učinek tretinoina se med izpostavljenostjo svetlobi poslabša (17).

Najpogostejši neželeni učinki zdravljenja s topikalnim retinoidom so draženje kože, suha koža in luščenje kože. Ti so najbolj opazni v prvem mesecu zdravljenja. Z zdravljenjem lahko začnemo postopno, npr. z nanašanjem vsak drugi ali tretji dan, s čimer zmanjšamo draženje kože, in s ciljem vsakodnevne uporabe, ko se toleranca izboljša. Druga možnost je, da bolniki začnejo $z$ vsakodnevno uporabo in preidejo na izmenični način mazanja, če začetno dnevno uporabo slabo prenašajo (13).

V Sloveniji so od topikalnih retinoidov trenutno dostopni adapalen $v$ obliki gela in kreme (Belakne ${ }^{\circledR} 1 \mathrm{mg} / \mathrm{g}$ gel in Belakne ${ }^{\circledR} 1 \mathrm{mg} / \mathrm{g}$ krema) ter kombinacija klindamicina in tretinoina $v$ gelu (Zalna ${ }^{\circledR} 10 \mathrm{mg} / 0,25 \mathrm{mg}$ v $1 \mathrm{~g}$ gel).

\section{Azelainska kislina}

20-odstotna azelainska kislina je učinkovina, ki deluje komedolitično, protibakterijsko in protivnetno, ob redni uporabi pa lahko izboljša tudi povnetno hiperpigmentacijo. Na kožo jo praviloma nanašamo dvakrat na dan. Neželeni učinek zdravljenja z azelainsko kislino je lahko lokalno draženje kože, npr. pekoč občutek, srbenje, pordelost, luščenje. Večinoma so simptomi draženja blagi in med zdravljenjem praviloma izzvenijo. Azelainsko kislino uvrščamo v nosečnostno kategorijo $B$ po $\operatorname{FDA}(2,13)$.

$\checkmark$ Sloveniji je trenutno na voljo 20-odstotna azelainska kislina v kremi (Skinoren ${ }^{\circledR} 200$ mg/g krema).

\section{Salicilna kislina}

Salicilna kislina je komedolitično sredstvo, ki je na voljo v prosti prodaji v jakosti 0,5-2 \%. V kliničnih preizkušanjih so ugotovili, da ima omejeno učinkovitost (2). Najdemo jo lahko v posameznih izdelkih medicinske kozmetike za nego kože, nagnjene $k$ aknam, kot učinkovina za zdravljenje aken pa na recept ni dostopna.

\section{Benzoil peroksid}

Benzoil peroksid je sredstvo, ki deluje protiibakterijsko in komedolitično. $\mathrm{Na}$ voljo je v koncentracijah od 2,5\% do $10 \%$ v različnih oblikah (kremah, losjonih, gelih). Običajno ga na kožo nanašamo enkrat na dan. Lahko ga uporabljamo kot samostojno protimikrobno sredstvo. Bolnike moramo opozoriti, da lahko povzroči beljenje tkanin ali las in draženje kože, zlasti v višjih koncentracijah (13).

Če topikalni ali oralni antibiotik kombiniramo $z$ benzoil peroksidom, izboljšamo učinkovitost zdravljenja in zmanjšamo razvoj odpornosti bakterijskih sevov na predpisani antibiotik (2).

V Sloveniji benzoil peroksid trenutno kot učinkovina na recept ni na voljo.

Topikalni antibiotik (1 \% klindamicin, $2 \%$ eritromicin)

Topikalne antibiotike uporabljamo za papulopustulozne akne. Topikalni klindamicin na prizadeto kožo nanesemo dvakrat na dan. $V$ kombinaciji z benzoil peroksidom izboljšamo učinkovitost in zmanjšamo razvoj odpornosti bakterij na antibiotik $(2,13)$. Topikalni eritromicin je alternativa klindamicinu, a ima klindamicin zaradi pojava večje odpornosti bakterij Cutibacterium ob uporabi eritromicina prednost (2).

Toleranca topičnih antibiotikov je odlična. $V$ literaturi kot redka neželena učinka topikalnega klindamicina opisujejo pojav driske ali C. difficile kolitisa (18).

Klindamicin uvrščamo $v$ nosečnostno kategorijo B po FDA (2).

V Sloveniji so trenutno dostopni dermalna raztopina $1 \%$ klindamicina (Klindamicin $1 \%$ dermalna raztopina), kombinacija klindamicina in tretinoina $v$ gelu (Zalna ${ }^{\circledR} 10 \mathrm{mg} / 0,25 \mathrm{mg} v 1 \mathrm{~g}$ gel) in na magistralni predpis $1,8 \%$ klindamicin tekoči puder.
Druge možnosti za zdravljenje blagih aken so še topikalni dapson, topikalni minociklin in topikalni klaskoteron. Nobenega od teh treh pripravkov trenutno v Sloveniji ni mogoče dobiti.

Na splošno se izboljšanje pri zdravljenju blagih aken pokaže v 12 tednih. Vzroki neuspešnosti zdravljenja so nedosledno upoštevanje načina zdravljenja, napačna diagnoza ali pridružene bolezni (npr. hiperandrogenizem). Način zdravljenja prilagodimo posamezniku in je odvisen od klinične slike bolezni, bolnikovega upoštevanja trenutnega načina zdravljenja in bolnikovih želja (13).

\section{Zdravljenje zmerne in hude oblike aken}

Če pri kliničnem pregledu ugotovimo, da lokalno zdravljenje aken ni učinkovito, ali opažamo podkožne noduse, obsežno prizadetost kože, brazgotine in duševne težave, ki so posledica aken, bolnika napotimo $\mathrm{h}$ dermatologu, saj je praviloma potrebno sistemsko zdravljenje. Med sistemskimi zdravili uporabljamo oralne antibiotike (predvsem tetracikline), hormonsko zdravljenje (oralna kontracepcijska sredstva ali spironolakton) in oralni izotretinoin. Sistemsko zdravljenje kombiniramo z lokalnim zdravljenjem, izjema je oralni izotretinoin, ki ga - ko se pokaže njegov pravi učinek - predpisujemo samostojno. Tudi oralnega antibiotika ne kombiniramo s topikalnim antibiotikom. Oralni izotretinoin, oralna kontracepcijska sredstva in spironolakton predpisujemo pri vseh oblikah zmernih in hudih aken, medtem ko so oralni antibiotiki bolj primerni za papulopustolozne in nodularne akne (19).

\section{Oralni izotretinoin}

Je izomer retinoične kisline in ga uporabljamo za zdravljenje hudih nodularnih aken. V klinični praksi uporabljamo tudi pri manj hudih aknah, ki so odporne na druge načine zdravljenja in puščajo brazgotine $(2,19)$. 
Oralni izotretinoin je edino zdravilo proti aknam, ki deluje na vse štiri dejavnike v patogenezi aken. Zmanjša prekomerno izločanje loja, vpliva na folikularno hiperkeratinizacijo in zmanjša deskvamacijo, zavira proliferacijo bakterij Cutibacterium ter umirja vnetje. Zdravljenje z izotretinoinom traja več mesecev in ga običajno predpisujemo kot monoterapijo (19). Začetni odmerek je $0,5 \mathrm{mg} / \mathrm{kg} / \mathrm{dan}$ prvi mesec, ki ga nato povečujemo do 1,0 $\mathrm{mg} / \mathrm{kg} / \mathrm{dan}$, če bolnik zdravljenje dobro prenaša (20).

Pri bolnikih s hudimi aknami je v začetku zdravljenja učinkovita kombinacija oralnega izotretinoina in sistemskega glukokortikoida (19).

Izotretinoin je teratogeno zdravilo in zato kontraindicirano $v$ nosečnosti in pri ženskah v rodni dobi, razen ob izpolnjevanju vseh pogojev preprečevanja nosečnosti.

Najpogostejši neželeni učinki zdravljenja z oralnim izotretinoinom so suha koža in sluznice, motnje vida (predvsem nočnega), hiperlipidemija, zvišanje vrednosti jetrnih transaminaz in mialgija (19).

V Sloveniji je oralni izotretinoin na voljo (Roaccutane ${ }^{\circledR} 10 \mathrm{mg}$ ali $20 \mathrm{mg}$ mehke kapsule), predpisovanje in izdaja zdravila pa sta možna le na recept zdravnika specialista dermatologa ali od njega pooblaščenega zdravnika.

\section{Oralni antibiotiki}

Oralni antibiotiki so indicirani za zmerne in hude vnete akne in jih predpisujemo $v$ kombinaciji s topikalnimi retinoidi in benzoil peroksidom (21).

Oralni antibiotiki izboljšajo vnetne spremembe aken z zaviranjem rasti bakterij Cutibacterium znotraj pilosebacealne enote, nekateri pa imajo tudi protivnetne učinke $z$ inhibiranjem kemotakse levkocitov in metaloproteinazne aktivnosti vnetnih celic $(2,19)$.

Tetraciklini (doksiciklin, minociklin, sareciklin) so za zdravljenje aken naj- bolj primerni sistemski antibiotiki predvsem zaradi učinkovitosti in prenašanja. Drugi antibiotiki (makrolidi, trimetoprim-sulfametoksazol, cefalosporini in penicilini) so namenjeni bolnikom, ki tetraciklinov ne prenašajo (2). Pri teh bolnikih sicer običajno predpišemo oralni izotretinoin (19).

Sistemsko antibiotično zdravljenje traja 3-4 mesece ob hkratni uporabi topikalnega retinoida, s katerim nadaljujemo tudi po zaključku antibiotičnega zdravljenja (2).

Pri predpisovanju sistemskega antibiotičnega zdravljenja se pojavlja vprašanje odpornosti na predpisani antibiotik, ki jo najpogosteje opisujejo v povezavi z jemanjem eritromicina. Dodatek benzoil peroksida zdravljenju s sistemskim antibiotikom zmanjša razvoj odpornosti $(2,19)$.

Doksiciklin predpisujemo adolescentom in odraslim v odmerku $50 \mathrm{mg}$ ali $100 \mathrm{mg}$ dvakrat na dan ali $100 \mathrm{mg}$ enkrat na dan. Doksiciklina in drugih tetraciklinov zaradi tveganja za obarvanje zob ne predpisujemo otrokom do 8. leta starosti, prav tako jih ne predpisujemo nosečnicam. Doksiciklin lahko povzroči prebavne težave (ezofagitis, razjede na prebavilih, psevdomembranski kolitis), v kombinaciji z oralnim izotretinoinom pa lahko pride do pojava idiopatske znotrajlobanjske hipertenzije (pseudotumor cerebri). Po izpostavljenosti soncu se lahko pojavi fotosenzitivnostna reakcija, zato je koža bolj nagnjena k sončnim opeklinam (19). Minociklin predpisujemo v odmerku $50 \mathrm{mg}$ ali $100 \mathrm{mg}$ enkrat ali dvakrat na dan in ima v primerjavi z ostalimi tetraciklini hujše neželene učinke. Prehaja krvno-možgansko pregrado, zato lahko povzroči glavobol, omotico in vrtoglavico (19).

Od makrolidov pri zdravljenju aken uporabljamo azitromicin in eritromicin. Ker je pri njuni uporabi večja verjetnost nastanka odpornosti na predpisani antibiotik, niso prva izbira pri zdravljenju aken. Od neželenih učinkov je eritromicin povezan z višjo pojavnostjo driske in slabosti kot azitromicin. Makrolidi lahko povzročijo motnje v srčni prevodnosti in redko hepatotoksičnost. Opisujejo tudi povezanost azitromicina s kožno hipersenzitivnostno reakcijo (2).

V Sloveniji so od oralnih antibiotikov dostopni doksiciklin v obliki tablet (Doksivibra ${ }^{\circledR} 100$ mg disperzibilne tablete), azitromicin v obliki tablet, kapsul in praška za peroralno suspenzijo (Azibot ${ }^{\circledR} 500$ mg filmsko obležene tablete, Azitromicin Lek ${ }^{\circledR} 500$ mg filmsko obložene tablete, Sumamed ${ }^{\circledR} 500$ mg filmsko obložene tablete, Sumamed $^{\circledR} 250$ mg trde kapsule, Sumamed ${ }^{\circledR}$ $40 \mathrm{mg} / \mathrm{ml}$ prašek za peroralno suspenzijo) in eritromicin v obliki praška za raztopino za infundiranje (kar v praksi za zdravljenje aken ne pride v poštev).

\section{Oralno hormonsko zdravljenje}

Hormonsko zdravljenje $z$ oralnimi kontracepcijskimi sredstvi in/ali spironolaktonom je možnost zdravljenja aken za ženske. Ta zdravila vplivajo na androgene hormone tako, da zmanjšajo izločanje loja. Izbira hormonskega zdravljenja je odvisna od želje bolnika in potencialnih neželenih učinkov. Hormonsko zdravljenje z oralnimi kontracepcijskimi sredstvi predpisujejo predvsem ženskam, ki hkrati z izboljšanjem aken želijo tudi kontracepcijo. Ob odsotnosti kontraindikacij za tovrstno zdravljenje je bolje pričeti zdravljenje z oralnimi kontracepcijskimi sredstvi kot s spironolaktonom. Velja, da je hormonsko zdravljenje namenjeno dolgotrajnemu zdravljenju, da ohranimo izboljšanje. Začetno izboljšanje aken je pogosto odloženo, za oceno učinkovitosti pa je potrebno vsaj 3-6 mesecev zdravljenja (19).

Kombinirana oralna kontracepcijska sredstva, ki vsebujejo estrogen in progestin, so učinkovita zdravila za vulgarne akne pri ženskah. Nekateri progestini imajo antiandrogene lastnosti (npr. drospirenon, ciproteron acetat), drugi (npr. dezogestrel) pa ne in lahko akne celo poslabšajo $(19,22)$. 
komedonske akne

1. izbira

topikalni retinoid

komedonske in papulopustulozne akne

\section{topikalni retinoid +} topikalno protimikrobno zdravilo (BP* ali ATB**)

Alternativa

drugi topikalni retinoid ali azelainska kislina ali salicilna kislina drugo topikalno protimikrobno zdravilo + drugi topikalni retinoid ali azelainska kislina oralni ATB + topikalni oralni izotretionin retinoid + BP

drugi oralni ATB + drugi topikalni retinoid $+\mathrm{BP}$

oralni ATB + azelainska kislina ali oralni ATB + topikalni retinoid + BP ali oralni ATB + topikalni retinoid ali oralni ATB + BP

hormonsko zdravljenje + oralni ATB + topikalno zdravljenje
Alternativa za ženske glej 1. izbiro in alternativo glej 1. izbiro in alternativo hormonsko zdravljenje + topikalni retinoid ali azelainska kislina +/topikalno protimikrobno zdravilo (BP ali BP + ATB)
TABELA 1. POVZETEK SMERNIC ZA ZDRAVLJENJE VULGARNIH AKEN (PRIREJENO PO EVROPSKIH IN AMERIŠKIH SMERNICAH).

Legenda: *BP - benzoil peroksid, **ATB - antibiotik.
TABLE 1. SUMMARY OF ACNE TREATMENT GUIDELINES, ADAPTED FROM EUROPEAN AND AMERICAN GUIDELINES.

Legend: *BP: benzoil perokside, **ATB: antibiotic
Pri uporabi kombiniranih oralnih kontracepcijskih sredstev obstaja tveganje venske tromboze, ishemične in hemoragične kapi ter raka na dojki in na materničnem vratu. Povečano je tudi tveganje za miokardni infarkt ob dejavnikih tveganja, kot so kajenje, sladkorna bolezen in hipertenzija (2). Na splošno bi se predpisovanju kombiniranih oralnih kontracepcijskih sredstev izogibali dveh leti po menarhi pri bolnicah, ki so mlajše od 14 let, razen ob odsotnosti klinično utemeljenega razloga za tovrstno zdravljenje. FDA je odobrila uporabo kombiniranih oralnih kontracepcijskih sredstev pri ženskah, starih 14 let in več (2). V Sloveniji je uporaba kombiniranih oralnih kontracepcijskih sredstev za zdravljenje aken indicirana po menarhi.

Spironolakton je antiandrogen, ki blokira receptorje za androgene in inhibira biosintezo androgenov, kar vodi v zmanjšano tvorbo loja (23). Spironolakton bolnice na splošno dobro prenašajo, neželeni učinki pa so odvisni od odmerka in se kažejo kot povečana diureza, motnje menstrual- nega cikla, občutljivost in povečanje dojk, utrujenost, glavobol, omotica in hiperkalemija $(2,19)$. Hiperkalemija je potencialno resen neželeni učinek, a je tveganje hiperkalemije pri mladih, zdravih ženskah, ki se zdravijo zaradi aken, majhno, zato rutinsko preverjanje ravni kalija ni potrebno (24). Spironolakton sodi v nosečnostno kategorijo C, v raziskavah na živalih pa ugotavljajo feminizacijo moškega zarodka v zgodnjem nosečnostnem obdobju (2).

V Sloveniji je za zdravljenje aken dostopna in indicirana kombinacija etinilestradiola in ciproteron acetata (Diane ${ }^{\circledR} 0,035 \mathrm{mg} / 2 \mathrm{mg}$ obložene tablete).

V Sloveniji je spironolakton dostopen v obliki kapsul oz. tablet, a zdravljenje aken ni omenjeno med terapevtskimi indikacijami.

\section{Drugi načini zdravljenja}

Glede na klinično sliko se dermatologi občasno odločijo za zdravljenje z laserjem in drugimi svetlobnimi viri, ki jih lahko kombiniramo tudi z lokalnim zdravljenjem. Pri zdravljenju posledic aken, kot so spremembe pigmentacije kože ali brazgotine, uporabljamo tudi dodatne ukrepe, kot so dermoabrazija, lasersko zdravljenje, luščenje kože s kemičnimi sredstvi in drugo $(2,3)$.

\section{Posebnosti pri zdravljenju posebnih populacij}

Pri nekaterih bolnikih z aknami moramo pristop k zdravljenju prilagoditi. Mednje uvrščamo otroke in adolescence, nosečnice, bolnike z brazgotinami kot posledica aken, bolnike s temnejšo barvo kože, bolnike s hudimi aknami in bolnike z redkimi, z aknami povezanimi sindromi (13).

\section{Novorojenčki in dojenčki}

Pri novorojenčkih na pospešeno izločanje loja in pojav aken v prvih mesecih po rojstvu vplivajo transplacentarno preneseni materini androgeni hor- 
moni in neonatalni androgeni, ki so pri obeh spolih adrenalnega izvora, pri dečkih tudi testikularnega izvora. Dodatno lahko na pojav t. i. akniformnega izpuščaja vpliva tudi kolonizacija s kvasovko Malassezia spp.

Zvišana raven dihidroepiandrosterona (DHEA) stimulira lojnice do prvega leta starosti, nato pa se raven DHEA zniža. Malassezia spp. je saprofit normalne kožne flore, o vlogi kvasovke pri nastanku aken pa so mnenja deljena. Prispevala naj bi k močnejšemu vnetnemu odgovoru pri aknah (4).

Akne pri novorojenčkih in dojenčkih zdravimo z rednim umivanjem z blagim milom in vodo, $s$ kremo $z$ azelainsko kislino in z 1-odstotno raztopino klindamicina. Trdovratne papulopustulozne in nodulocistične akne zahtevajo dodatno obravnavo pri dermatologu (1).

\section{Otroci med 1. in 7. letom starosti}

Če se akne pojavijo pri otroku med 1. in 7. letom starosti, posumimo na hiperandrogenizem, zato iščemo znake prezgodnje pubertete. Potrebna je nadaljnja obravnava pri endokrinologu, ki z dodatnimi preiskavami, ki vključujejo rentgensko oceno kostne starosti in laboratorijske preiskave, ugotavlja vzrok prezgodnje pubertete (npr. androgen secernirajoči tumorji, kongenitalna adrenalna hiperplazija itd.) $(13,15)$.

\section{Preadolescenti otroci}

Pri preadolescentnih otrocih so vulgarne akne posledica normalnega razvoja in jih lahko zdravimo z zdravili, ki jih uporabljamo tudi pri najstnikih in odraslih. Zaradi škodljivih učinkov na razvoj zob se do 8. leta starosti izogibamo peroralnim tetraciklinom (15).

\section{Nosečnice}

Ko izbiramo med možnostmi zdravljenja aken pri nosečnicah, moramo imeti $v$ mislih morebitna tveganja in neželene učinke zdravila na plod.
Peroralni izotretinoin in lokalni tazaroten sta $v$ nosečnosti kontraindicirana in uvrščena $v$ kategorijo $X$ zdravil za čas nosečnosti. Poleg tega med nosečnostjo ni priporočljiva uporaba drugih lokalnih retinoidov (16). Nosečnice naj ne bi prejemale niti oralnih tetraciklinov, oralnih kontracepcijskih sredstev in spironolaktona (19).

\section{Bolniki z brazgotinami, ki so posledica aken}

Brazgotine zaradi aken so pozna posledica bolezni in pogosto izrazito vplivajo na kakovost bolnikovega življenja. Zato se pri bolnikih z nagnjenostjo $k$ brazgotinami po aknah že zgodaj odločamo o sistemskem zdravljenju. Povnetne hiperpigmentacije in povnetni eritem niso trajne posledice aken, lahko pa vztrajajo več mesecev in let, zato se tudi v primeru pojavljanja tovrstnih sprememb pogosto odločamo za sistemsko zdravljenje (13).

\section{Bolniki s temnejšo barvo kože}

Pozorni smo na bolnike z zmerno pigmentirano do močno pigmentirano kožo (fototipi IV-VI), saj ti povnetne hiperpigmentacije razvijejo bolj pogosto kot bolniki s svetlejšo poltjo (13).

\section{Bolniki s hudimi aknami}

Acne fulminans in acne conglobata sta hudi klinični prezentaciji vulgarnih aken in ju zdravimo z oralnim izotretinoinom (13).

Bolniki z redkimi sindromi, povezanimi $z$ aknami

Obstaja več redkih sindromov, povezanih z aknami. Med njimi sta pogostejša sindrom SAPHO (sinovitis, akne, pustuloza, hiperkeratoza, osteitis) in sindrom PAPA (piogeni artritis, pioderma gangrenosum, akne). Ti bolniki navadno potrebujejo dodatno diagnosticiranje in multidisciplinarni pristop $\mathrm{k}$ zdravljenju (13).

\section{Zaključek}

$\checkmark$ prispevku smo predstavili klinično sliko in stopenjsko zdravljenje aken, ki smo ga povzeli po najnovejših evropskih in ameriških smernicah za zdravljenje aken iz leta 2016. Vulgarne akne so najpogostejše pri najstnikih, a se pojavljajo tudi v drugih starostnih skupinah, pri katerih je zelo pomembno, da ugotovimo njihov vzrok. Zdravimo jih po strokovnih smernicah, ki vključujejo lokalno in sistemsko zdravljenje, možni pa so tudi drugi načini zdravljenja. Zdravljenje aken je praviloma individualno, tj. prilagojeno posameznemu bolniku, cilja zdravljenja pa sta dolgotrajna umiritev bolezni in bolnikovo zadovoljstvo.

\section{Literatura}

1. Starbek Zorko M. Osnove otroške dermatologije za pediatre: Zbornik tečaja. Ljubljana: Dermatovenerološka klinika. Univerzitetni klinični center. 2019.

2. Zaenglein AL, Pathy AL, Schlosser BJ, Alikhan A, Baldwin HE, Berson DS, et al. Guidelines of care for the management of acne vulgaris. J Am Acad Dermatol 2016; 74: 945.

3. Točkova O. Akne, kaj lahko storimo, $A B C$ zdravja, letnik 16, številka 1, januar 2021.

4. Herane $\mathrm{MI}$, Ando I. Acne in infancy and acne genetics. Dermatology 2003; 206; 24-8.

5. Yang $X Y$, Wu WJ, Yang C, Yang T, He JD, Yang Z, et al. Association of HSD17B3 and HSD3B1 polymorphisms with acne vulgaris in Southwestern Han Chinese. Dermatology 2013; 227; 202-8.

6. Navarini AA, Simpson MA, Weale M, Knight J, Carlavan I, Reiniche P, et al. Genome-wide association study identifies three novel susceptibility loci for severe Acne vulgaris. Nat Commun 2014; 5; 4020.

7. Cordain $L$, Lindeberg $S$, Hurtado $M$, Hill $K$, Eaton SB, Brand-Miller J. Acne vulgaris: a disease of Western civilization. Arch Dermatol 2002; 138; 1584-90.

8. Adebamowo CA, Spiegelman D, Danby FW, Frazier AL, Willett WC, Holmes MD. High school dietary dairy intake and teenage acne. J Am Acad Dermatol 2005; 52; 207-14.

9. Smith RN, Mann NJ, Braue A, Makelainen $H$, Varigos GA. A low-glycemic-load diet improves symptoms in acne vulgaris patients: a randomized controlled trial. Am J Clin Nutr 2007; 86; 107-15.

10. Dosegljivo na: https://dermnetnz.org/topics/ acne-excorie/

11. Dosegljivo na: https://www. dermis.net/dermisroot/en/36559/diagnose.htm. 
12. Mills Jr OH, Kligman AM, Acne aestivalis, Arch Dermatol 1975; 111(7): 891-2.

13. Graber E, Dellavalle RP, Levy ML, Owen $C$, Ofori AO. Acne vulgaris: Owerview of management. Dosegljivo na: https://www. uptodate.com/contents/acne-vulgaris-overviewof-management? search=acne\&source=se arch_result\&selectedTitle=1 150\&usage_ type $=$ default\&display_rank $=1$.

14. Nast A, Dreno B, Bettoli V, Bukvic M, Degitz K, Dressler $C$ et al. European evidence based (S3) guideline for the treatment of acne update 2016. Journal of the European Academy of Dermatology and Venereology 30 (8) , pp. 1261-8.

15. Eichenfield LF, Krakowski AC, Piggott $C$, et al. Evidence-based recommendations for the diagnosis and treatment of pediatric acne. Pediatrics 2013; 131 Suppl 3: S163.

16. Murase JE, Heller MM, Butler DC. Safety of dermatologic medications in pregnancy and lactation: Part I. Pregnancy. J Am Acad Dermatol 2014; 70:401.e1.

17. Nyirady J, Lucas $C$, Yusuf M, et al. The stability of tretinoin in tretinoin gel microsphere 0.1\%. Cutis 2002; 70: 295.

18. Becker LE, Bergstresser PR, Whiting DA, et al. Topical clindamycin therapy for acne vulgaris. A cooperative clinical study. Arch Dermatol 1981; 117: $482-5$

19. Graber E, Dellavalle RP, Levy ML, Owen $\mathrm{C}$, Ofori AO. Management of moderate to severe acne. Dosegljivo na: https://www. uptodate.com/contents/acne-vulgarismanagement-of-moderate-to-severeacne? search=acne\%20vulgaris \&source=search result\&selectedTitle $=2 \sim 150 \&$ usage

type $=$ default\&display_rank $=2$.

20. Goldsmith LA, Bolognia JL, Callen JP, et al. American Academy of Dermatology Consensus Conference on the safe and optimal use of isotretinoin: summary and recommendations. J Am Acad Dermatol 2004; 50: 900-6.

21. Gold LS, Cruz A, Eichenfield L, et al. Effective and safe combination therapy for severe acne vulgaris: a randomized, vehicle-controlled, double -blind study of adapalene $0.1 \%$-benzoyl peroxide $2.5 \%$ fixed-dose combination gel with doxycycline hyclate $100 \mathrm{mg}$. Cutis 2010; 85: 94-104.

22. Katsambas AD, Dessinioti $C$. Hormonal therapy for acne: why not as first line therapy? facts and controversies. Clin Dermatol 2010; 28: 17.

23. George R, Clarke S, Thiboutot D. Hormonal therapy for acne. Semin Cutan Med Surg 2008; 27: 188

24. Plovanich M, Weng QY, Mostaghimi A. Low usefulness of potassium monitoring among healthy young women taking spironolactone for acne. JAMA Dermatol 2015; 151: 941-4.
Manca Valjavec, dr. med.

Zdravstveni Dom Tržič, Tržič, Slovenija

Mateja Starbek Zorko, dr. med. (kontaktna oseba / contact person) Dermatovenerološka klinika Univerzitetni klinični center Ljubljana in Medicinska fakulteta Univerze v Ljubljani Zaloška cesta 2, 1000 Ljubljana, Slovenija e-naslov: mateja.starbekzorko@kclj.si

prispelo / received: 6. 5. 2021

sprejeto / accepted: 19. 7. 2021

Valjavec M, Starbek Zorko M, Priporočila za zdravljenje aken, povzeta po najnovejših mednarodnih smernicah. Slov Pediatr 2021; 28(3): 123-129. https://doi.org/10.38031/ slovpediatr-2021-3-03. 